University of Nebraska - Lincoln

DigitalCommons@University of Nebraska - Lincoln

Papers in the Earth and Atmospheric Sciences Earth and Atmospheric Sciences, Department

\title{
Millennial-Scale Climate Variability during the Last Glacial Period in the Tropical Andes
}

Sherilyn C. Fritz

University of Nebraska-Lincoln, sfritz2@unl.edu

P. A. Baker

Duke University, pbaker@duke.edu

E. Ekdahl

University of Nebraska-Lincoln

G. O. Seltzer

Syracuse University

L. R. Stevens

University of Nebraska-Lincoln

Follow this and additional works at: https://digitalcommons.unl.edu/geosciencefacpub

Part of the Earth Sciences Commons

Fritz, Sherilyn C.; Baker, P. A.; Ekdahl, E.; Seltzer, G. O.; and Stevens, L. R., "Millennial-Scale Climate Variability during the Last Glacial Period in the Tropical Andes" (2010). Papers in the Earth and Atmospheric Sciences. 122.

https://digitalcommons.unl.edu/geosciencefacpub/122

This Article is brought to you for free and open access by the Earth and Atmospheric Sciences, Department of at DigitalCommons@University of Nebraska - Lincoln. It has been accepted for inclusion in Papers in the Earth and Atmospheric Sciences by an authorized administrator of DigitalCommons@University of Nebraska - Lincoln. 
Published in Quaternary Science Reviews 29:7-8 (April 2010), pp. 1017-1024; doi: 10.1016/j.quascirev.2010.01.001

Copyright ( 2010 Elsevier Ltd. Used by permission. http:/ / www.sciencedirect.com/science/journal/02773791

Submitted September 2, 2009; revised December 31, 2009; accepted January 4, 2010; published online February 1, 2010.

\title{
Millennial-Scale Climate Variability during the Last Glacial Period in the Tropical Andes
}

\author{
S. C. Fritz, ${ }^{1}$ P. A. Baker, ${ }^{2}$ E. Ekdahl, ${ }^{1}$ G. O. Seltzer, ${ }^{3}$ and L. R. Stevens ${ }^{1}$ \\ 1. Department of Geosciences and School of Biological Sciences, University of Nebraska-Lincoln, Lincoln, NE 68588-0340, USA \\ 2. Division of Earth and Ocean Sciences and Nicholas School of the Environment, Duke University, Durham, NC 27708, USA \\ 3. Department of Earth Sciences, Syracuse University, Syracuse, NY 13244, USA \\ Corresponding author - S. C. Fritz, tel 402 472-6431, fax 402 472-4917, email sfritz2@unl.edu
}

\begin{abstract}
Millennial-scale climate variation during the Last Glacial period is evident in many locations worldwide, but it is unclear if such variation occurred in the interior of tropical South America, and, if so, how the low-latitude variation was related to its high-latitude counterpart. A high-resolution record, derived from the deep drilling of sediments on the floor of Lake Titicaca in the southern tropical Andes, is presented that shows clear evidence of millennial-scale climate variation between $\sim 60$ and $20 \mathrm{ka}$ BP. This variation is manifested by alternations of two interbedded sedimentary units. The two units have distinctive sedimentary, geochemical, and paleobiotic properties that are controlled by the relative abundance of terrigenous or nearshore components versus pelagic components. The sediments of more terrigenous or nearshore nature likely were deposited during regionally wetter climates when river transport of water and sediment was higher, whereas the sediments of more pelagic character were deposited during somewhat drier climates regionally. The majority of the wet periods inferred from the Lake Titicaca sediment record are correlated with the cold events in the Greenland ice cores and North Atlantic sediment cores, indicating that increased intensity of the South American summer monsoon was part of near-global scale climate excursions.
\end{abstract}

\section{Introduction}

During portions of the Last Glacial stage, the climate of the high-latitude North Atlantic region was characterized by rapid transitions from cold stadial conditions to warm interstadial conditions. These stadial and interstadial events were particularly well developed between about 60 and $20 \mathrm{ka} \mathrm{BP}$, when they had an average pacing of about $1500 \mathrm{yr}$ (e.g. Dansgaard et al., 1993; NGRIP, 2004) and attained nearly two-thirds of the full glacial-interglacial amplitude. The North Atlantic millennial variation is anti-phased with Antarctic temperature change - Antarctic warming preceded the abrupt northern D-O warming, and the amplitude of Antarctic temperature change is correlated with the duration of the contemporaneous northern stadial (Blunier and Brook, 2001; EPICA, 2006). This anti-phased relationship may stem from large-amplitude changes in the rate of Atlantic meridional overturning circulation and related changes in meridional oceanic heat transport from the southern to the northern hemisphere (see review by Clement and Peterson, 2008).

Millennial-scale climate variability during the Last Glacial period also is evident in many other locations worldwide
(Voelker, 2002), including the tropical oceans (e.g. Arz et al., 1998; Peterson et al., 2000; Stott et al., 2002; Jennerjahn et al., 2004), as well as in the monsoon domains of Asia, East Africa, and Australia (e.g. Schulz et al., 1998; Wang et al., 2001; Altabet et al., 2002; Burns et al., 2003; Turney et al., 2004; Brown et al., 2007). In the tropical Atlantic Ocean it is apparent that northern hemisphere stadials were accompanied by southward shifts of the Inter tropical Convergence Zone (ITCZ), as observed in records (e.g. Arz et al., 1998; Peterson et al., 2000) and confirmed in many different model simulations (e.g. Vellinga and Wood, 2002; Chiang et al., 2003; Chiang and Bitz, 2005; Zhang and Delworth, 2005; Broccoli et al., 2006; Liu et al., 2009). Likewise, in the northern terrestrial tropics, northern hemisphere stadials were accompanied by weakened East Asian (e.g. Wang et al., 2001) and Indian monsoons (e.g. Schulz et al., 1998; Burns et al., 2003; Sinha et al., 2005). Records of the West African summer monsoon thus far contain less clear evidence of similar millennial variability during the full glacial (Weldeab et al., 2007; Itambi et al., 2009).

In the South American tropics, high-resolution speleothem records from Botuverá Cave $\left(27^{\circ} \mathrm{S}\right)$, near the region where the South American low-level jet exits the continent, reveal mil- 
lennial climate variability thought to be associated with variability of the South American summer monsoon (SASM) during the last full glacial (Cruz et al., 2005; Wang et al., 2006; Wang et al., 2007a). At these time scales, the intensity of the SASM was anti-phased with the intensity of the summer monsoon in China - during cold northern stadials, the Asian summer monsoon was apparently less intense while wetter conditions occurred in the SASM sector (Wang et al., 2006; Wang et al., 2007a). In the Nordeste region of Brazil, a lower resolution speleothem record also implies periods of enhanced precipitation that coincide with the northern stadials (Wang et al., 2004), and this is confirmed by a marine record of terrestrial runoff from the Nordeste at about $6^{\circ} \mathrm{S}$ (Arz et al., 1998). Likewise, a speleothem record from Paraiso Cave in the eastern Amazon at about $4^{\circ} \mathrm{S}$ (Wang et al., 2007b) also indicates wet conditions coincident with cold northern stadials. However, farther into the continental interior of tropical South America, largely because of the absence of high-resolution paleoclimatic records that span the Last Glacial period, it is not yet known if similar millennial climate variability occurred. Here we present evidence from a drill core record from Lake Titicaca in the southern tropical Andes that also shows clear evidence of millennial-scale climate variation between $\sim 60$ and $20 \mathrm{ka} \mathrm{BP.} \mathrm{Al-}$ though the chronology is insufficient for us to unambiguously correlate each climatic event observed in the record with a northern hemisphere counterpart, we conclude, on the basis of their common pacing and the similar timing, that such a correlation does in fact exist. We posit that each North Atlantic stadial was correlated with, and perhaps responsible for, wet intervals in the southern tropical Andes.

\section{Regional setting}

Lake Titicaca $\left(15-17^{\circ} \mathrm{S}, 68.5-70^{\circ} \mathrm{W}\right.$, Figure 1$)$ is a large $\left(8559 \mathrm{~km}^{2}\right)$, deep (285 $\mathrm{m}$ maximum depth), high-elevation ( $3810 \mathrm{~m}$ above sea level) lake on the South American Altiplano, an internally drained high-elevation plateau located between the eastern and western cordilleras of the Andes.

Precipitation in the Lake Titicaca watershed is largely a product of the SASM (Zhou and Lau, 1998), a near-continental-scale circulation that transports moisture in a low-level counter-clockwise gyre, along a trajectory originating in the tropical Atlantic, westward across the Amazon basin, and southeastward along the eastern flank of the Andes. Some of this moisture is uplifted onto the Altiplano. The majority $(\sim 80 \%)$ of precipitation at Lake Titicaca occurs in the austral
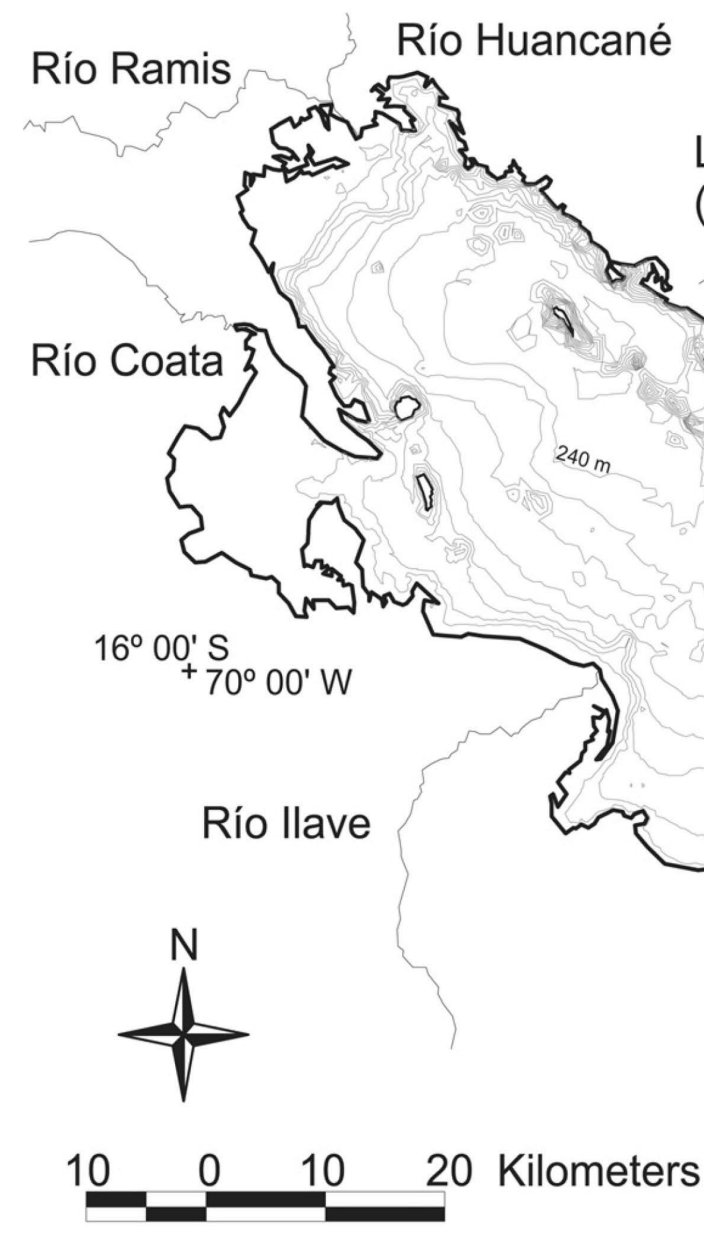

Contour Interval $30 \mathrm{~m}$ Lago Grande
(Lago Chucuito) Shoreline Elevation 3809 m
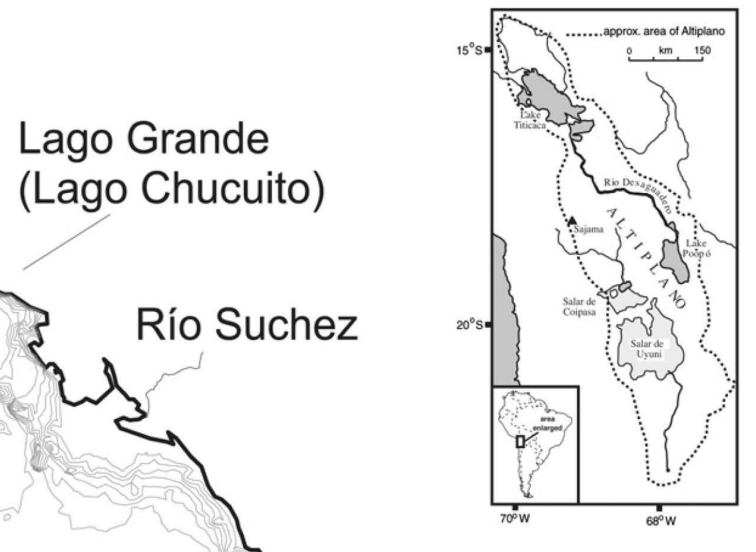
summer (DJFM), and precipitation amounts vary from $\sim 700$ to $\sim 1100 \mathrm{~mm} \mathrm{yr}^{-1}$ at different locations around the lake.

Today, about half of the water that enters the lake does so in the form of direct precipitation on the lake surface, and the remainder enters as a result of discharge of several major rivers (Figure 1) (Roche et al., 1992). Evaporation accounted for $>90 \%$ of the annual water loss from the lake during the late twentieth century, and evaporation rate is relatively constant from year to year (Kittel and Richerson, 1978). Consequently, inter-annual lake-level variations are primarily controlled by variations in the amount of summer precipitation (Baker et al., 2001).

During the instrumental period, a significant portion of the inter-annual variation of Altiplano precipitation was forced by sea-surface temperature (SST) variation in the tropical Pacific (Vuille et al., 2000; Vuille et al., 2003; Garreaud et al., 2009) and tropical Atlantic (Hastenrath et al., 2004; Cox et al., 2008). It is hypothesized that SST variation in both the tropical Pacific (Bradley et al., 2003) and tropical Atlantic (Melice and Roucou, 1998; Baker et al., 2001; Baker et al., 2005; Baker et al., 2009; Cook and Vizy, 2006) also played a role in forcing decadal to millennialscale variation in Altiplano precipitation, as revealed in the paleoclimatic record of the Holocene and Last Glacial maximum.

\section{Materials and methods}

In 2001, we collected overlapping drill cores from $235 \mathrm{~m}$ water depth at site LT01-2B in Lake Titicaca (Figure 1) using the GLAD-800 coring system (Fritz et al., 2007). The total depth of recovery at this site was $136 \mathrm{~m}$. Here we report on detailed sedimentologic, geochemical, and paleoecological analyses undertaken on sediments between 4 and $42 \mathrm{~m}$ subbottom. This section of core was recovered using hydraulic piston coring, thus core disturbance was minimal, and core recovery was nearly complete. The cores were shipped as whole rounds to the US and subsequently stored at the refrigerated LacCore core repository at the University of Minnesota. Cores were continuously logged with a Geotek logger for magnetic susceptibility, P-wave velocity, and gamma-ray porosity. The cores were then split, photographed, and described visually and with the aid of optical microscopy. In this interval, working halves of the cores were sampled at $10 \mathrm{~cm}$ increments, and these sub-samples were stored at $4{ }^{\circ} \mathrm{C}$ until processed further.

Samples for diatom analysis were digested in cold hydrogen peroxide and rinsed with distilled water. The cleaned subsamples were dried onto cover slips and affixed onto slides with Naphrax. Diatoms were counted at 1000× magnification on a Leica DMRX microscope with differential interference contrast (DIC). At least 300 diatom valves were counted in each sample. Benthic diatom abundance was calculated as the percentage of benthic valves relative to the total number of identified diatom valves. Biogenic silica (BSi) values were measured spectrophotometrically after a 1-h $1 \% \mathrm{Na}_{2} \mathrm{CO}_{3}$ extraction at $80^{\circ} \mathrm{C}$, following the methodology of DeMaster (1979). The precision of measurement was 1-2\%. Prior analysis of sediments spanning the length of the core using a 1$5 \mathrm{~h}$ time-course extraction determined that BSi extraction was complete within $1 \mathrm{~h}$. Conversions of BSi data to mass accumulation rates have little influence on the results and do not appreciably change the shape of the time series analysis and the resultant periodic pattern in the data (see below).

Samples for analysis of organic carbon and its isotopic composition were dried, powdered, weighed, and leached in buffered $(\mathrm{pH}=5.5)$ ammonium acetate-acetic acid. The insoluble residue was rinsed in reagent-grade water, and portions of this material were dried and weighed prior to determination of organic $C$ and its stable isotopic composition using a Finnegan MAT Delta Plus XL mass spectrometer in the Duke University Environmental Stable Isotope Laboratory. Carbon isotopic ratios are reported relative to the PDB standard; the precision for measurements was $\pm 0.2 \%$. Samples for grain-size analysis were treated with dilute hydrochloric acid, concentrated hydrogen peroxide, and hot $1 \mathrm{M} \mathrm{NaOH}$ to remove, respectively, carbonates, organic matter, and biogenic silica. Samples were rinsed, centrifuged, and dispersed in sodium metaphosphate and analyzed with a Coulter laser diffractometer.

An age model for the entire LT01-2B core was developed based on radiocarbon, U-series measurements on aragonite laminae, and tuning of basal calcium carbonate peaks to the Vostok $\mathrm{CO}_{2}$ record (see Fritz et al., 2007 for details). In the analyses presented here, we focus on the sediments from the period 20-60 ka BP (4.08-41.98 m below lake floor, mblf), when stadialinterstadial variability is best expressed in the northern high latitudes (NGRIP, 2004). In this section of the drill core, the chronology is based upon 12 AMS ${ }^{14} \mathrm{C}$ dates (Figure 2). To generate ages for the lower part of the glacial sequence beyond the range of radiocarbon, the age-depth relationship established in the oldest ${ }^{14} \mathrm{C}$-dated portion of the sediments was extrapolated back to $41.98 \mathrm{mblf}$, which is the lowermost depth of the most recent glacial unit based on sediment physical properties and magnetic susceptibility measurements (Fritz et al., 2007). This extrapolation is justified based on the uniform lithology in this section of the core. In the sequence presented here, our age model generates an average sample resolution of $125 \mathrm{yr}$ for BSi and $\delta^{13} \mathrm{C}$ of TOC; $240 \mathrm{yr}$ for grain size and benthic diatom abundance.

To evaluate the pacing of variability in the Lake Titicaca stratigraphic record, we examined the BSi data using the multi-taper method of spectral analysis (Mann and Lees, 1996). We used the BSi data for this analysis, because they were sampled at the highest resolution, and they reveal the most distinctive variability (Figure 3). Prior to spectral analysis, that record was re-sampled to create a uniformly spaced time series and normalized to unit variance using the program Analyseries (Paillard et al., 1996). The re-sampled time series has a uniform spacing of 100 years, allowing for resolution of periodic signals with periods of 200 years.

\section{Results}

The LT01-2B core contains two major sedimentary units throughout its entire 136-m length: (1) carbonate-rich laminated muds, and (2) massive gray muds that have higher magnetic

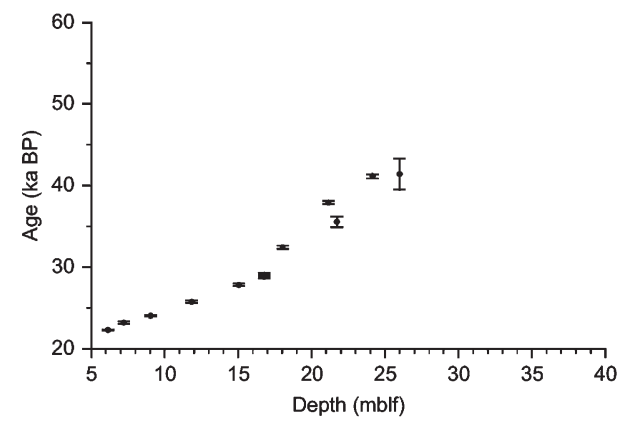

Figure 2. Calibrated radiocarbon ages for the lower portion of the LT01-2B drill core based on calibrated radiocarbon measurements on bulk organic carbon. Between 4.38 and 15.69 mblf, age (cal yr BP) was calculated from depth $(x)$ as $y r=613 x+18,563$. Between 15.69 and 41.98 mblf, yr $=1412 x+6023$. See Fritz et al. (2007) for additional information on chronology and age model construction. 


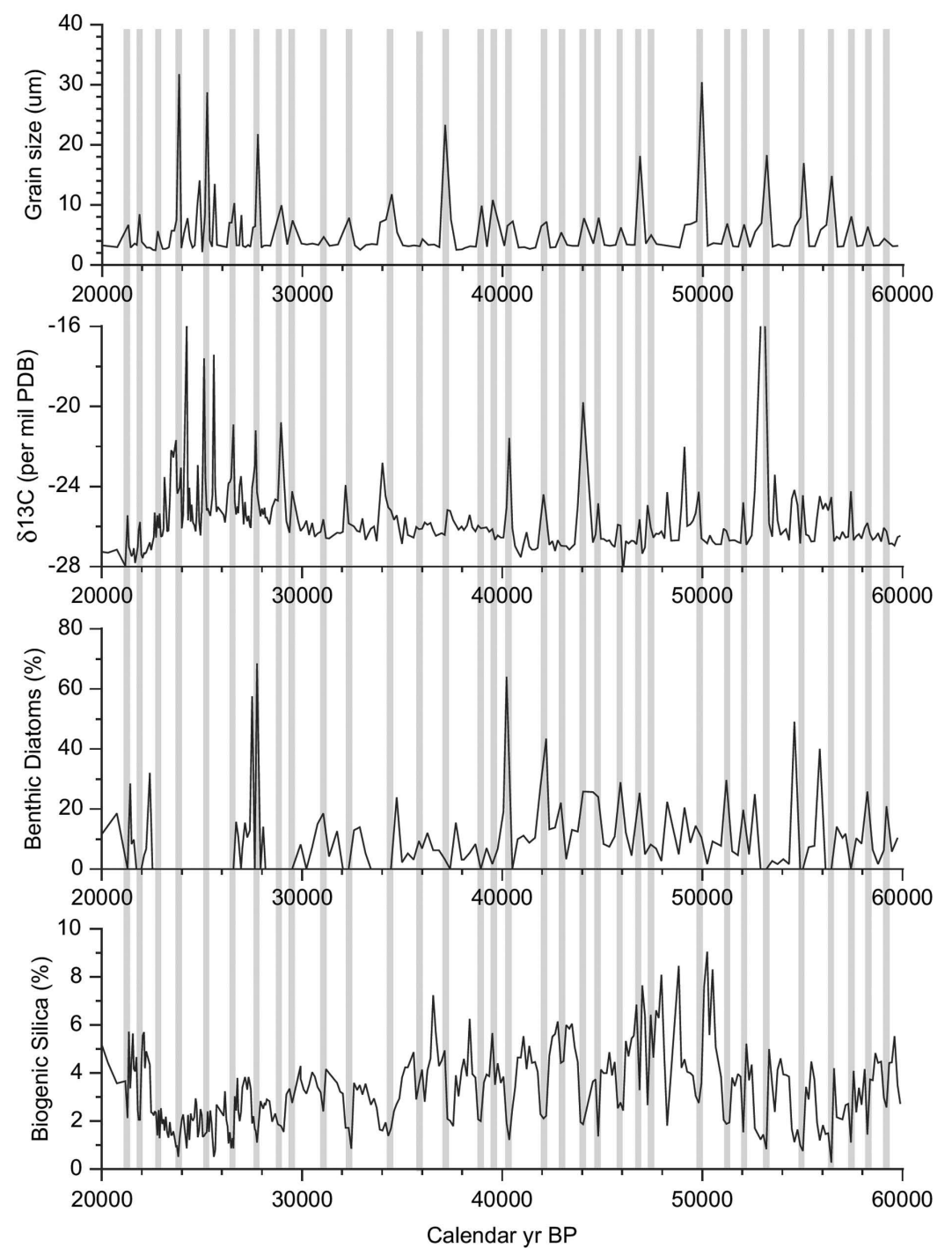

Figure 3. Stratigraphy of select proxies in the LT01-2B drill core in the section of the core spanning from 20 to $60 \mathrm{ka}$. Vertical gray lines mark peaks in the grain-size data. Note that grain size and benthic diatoms were sampled at lower resolution than BSi and $\delta^{13} \mathrm{C}$. Also note that there is poor preservation of diatom assemblages and BSi between 26.6 and $22.5 \mathrm{ka} \mathrm{BP}$.

susceptibility, lower organic carbon concentrations, and no carbonate (here we use "mud" to signify sediment that is a mixture of silt and clay-sized particles). Based on our prior studies (Baker et al., 2001; Seltzer et al., 2002), these units, respectively, indicate deposition during orbital-scale (1) dry interglacial periods when lake level typically remained below the outlet, thus salinity in the lake increased and abundant calcium carbonate precipitated, and (2) wet glacial periods in which the lake was deep, overflowing, and fresh, thus little calcium carbonate was precipitated or preserved. In the present study, we focus entirely on sediments of the latter facies type - sediments (between 4 and 42 mblf) deposited during a period when glacial conditions prevailed globally and, most likely, locally. During this time period, relatively high rates of precipitation coupled with depressed temperatures brought about a positive hydrologic balance manifested by high lake levels in Lake Titicaca (Fritz et al., 2007). The cold and wet conditions most likely also brought about a positive glacial mass balance and glacial expansion in the Andean cordilleras in the eastern portion of the Lake Titicaca drainage basin (it should be noted, however, that thus far there are no glacial moraines in the region dated be- tween 60 and 30 ka; Smith et al., 2008; Zech et al., 2008). During this period, clastic sediment was transported by rivers (such as the Rio Suches), with greatly enhanced discharge and sediment loads, and delivered in large quantities to subaqueous deltas and the eastern abyssal basin of Lake Titicaca (Fritz et al., 2007). Watershed erosion rates were enhanced by both increased glacial erosion rates in the highlands and increased runoff from the unglaciated land surface. By contrast, during warmer and generally drier interglacial periods (represented by sediments above 4 mblf and below $42 \mathrm{mblf}$ ), the glaciers of the Cordillera Real retreated behind terminal moraines, erosion rates decreased, and deposition rates of sediments in Lake Titicaca decreased dramatically (Seltzer et al., 2002). The sediments immediately below 42 mblf are green to brown, laminated, high in carbonate, and low in magnetic susceptibility. Thus, this depth (42 mblf) marks the transition from the penultimate interglacial period to the most recent cold and wet glacial interval (Fritz et al., 2007).

The gray muds of the Last Glacial period (4-42 mblf) are not, in fact, entirely massive, as they appear by visual analysis alone. These sediments contain several thin ( $\mathrm{mm}$ - to cm-scale) silt lam- 
ina that we believe to be distal turbidites. More importantly, a variety of analyses reveal that the sediments are subtly bedded on a half-meter scale. For example, grain-size analysis reveals two distinct populations of muds (Figure 4). These populations are neatly separated by a mean grain size of $3.9 \mu \mathrm{m}$. Those muds with mean grain size finer than $3.9 \mu$ m (clay size) comprise $60 \%$ of all of the sediments in the studied interval. Muds with mean grain sizes greater than $3.9 \mu \mathrm{m}$ (very fine silt), ranging upward to about $32 \mu \mathrm{m}$ (coarse silt), comprise the remaining $40 \%$ of the studied sediments. The coarser-grained muds occur in beds averaging $39 \mathrm{~cm}$ thick, separated by somewhat thicker beds (averaging $57 \mathrm{~cm}$ thick) of the finer-grained mud.

The coarser and finer beds also differ in other ways besides texture. In nearly all cases, the coarser-grained muds also contain higher fractions of benthic diatoms in the total diatom assemblage, lower contents of biogenic silica and organic carbon, and higher values of $\delta^{13} \mathrm{C}_{\text {org }}$ (some of these relationships are shown in Figure 3). We have shown previously that higher $\delta^{13} \mathrm{C}_{\text {org }}$ values in sediments from Lake Titicaca are characteristic of organic matter derived from aquatic macrophyte populations in nearshore areas of the lake (Cross et al., 2000). Benthic diatom abundance is commonly low $(<20 \%)$ throughout the sequence reported on here, as is characteristic of deep-water sites in the lake (Tapia et al., 2003), but the highest benthic diatom abundances occur in the coarser muds. Biogenic silica is derived from both planktic and benthic diatoms, but the biogenic silica fraction of the sediments is greatly affected by dilution - large quantities of terrigenous detrital sediment in the coarser muds dilute the biogenic silica content of the sediment. Likewise, organic carbon is derived from both benthic and planktic sources, but low-carbon terrigenous detrital sediment input dilutes the organic carbon content of the coarser muds.

In summary, sediments deposited during the Last Glacial (60$20 \mathrm{ka} \mathrm{BP}$ ) are of two interbedded types: muds dominated by claysized particles and muds dominated by silt-sized particles. The

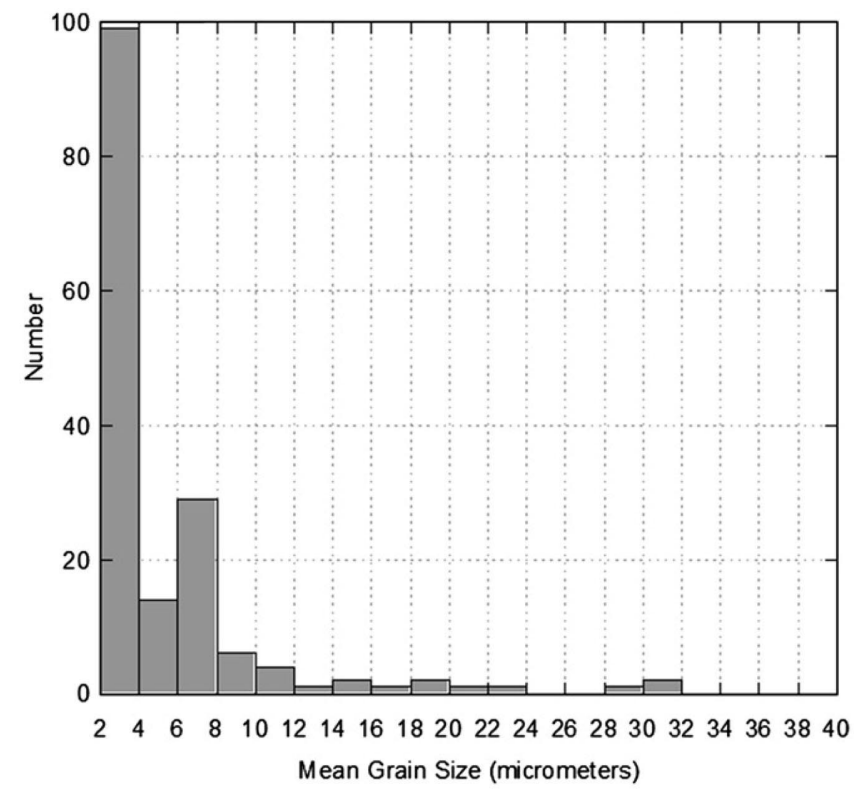

Figure 4. The number of analyzed samples with grain-size ranges characteristic of the two sub-units within the glacial-age sediments. The distribution of mean grain size is bimodal. Each sample with grain size $>3.9 \mu \mathrm{m}$ is part of a coarser-grained unit. These coarser sediments range in grain size from very fine silt $(>3.9 \mu \mathrm{m})$ to coarse silt $(<62.5 \mu \mathrm{m})$. The finer-grained muds contain clay-size sediments $(<3.9 \mu \mathrm{m})$. former comprise $60 \%$ of the sediments and, because the two sediment types alternate, the finer lithology occurs in beds that are about $50 \%$ thicker than the coarser lithology. The finer lithology, although it too contains predominantly allochthonous sediment, has a more pelagic nature than the coarser lithology. By contrast, the coarser-grained lithology contains a higher fraction of sediments of allochthonous and nearshore origin and very low concentrations of pelagic components. We posit that this alternation between allochthonous and pelagic sedimentation is due to alternation between wetter conditions and drier conditions.

\section{Discussion}

Millennial-scale variability is evident in the record of multiple proxies in the analyzed sediments that date from 60 to 20 ka BP (Figure 3). Textural evidence, coupled with the geochemical and biotic data, indicates that this variability is associated with alternating deposition of coarser- and finer-grained sediments in the coring location. The paleobiotic and geochemical composition of the coarser muds attests to their shallowwater and allochthonous origin. By contrast, higher fractions of planktic diatoms, higher BSi and organic carbon, and more negative values of $\delta^{13} \mathrm{C}_{\text {org }}$ indicate the more pelagic nature of the finer muds. In contrast to the rest of the 136-m LT01-2B drill core sequence, the repeated alternation of coarser and finer sediments during a continuously high lake stage is unique to this one section of the drill core (4-42 mblf). The high lake stage and positive hydrologic balance that prevailed throughout this interval implies that the local climate, although variable, was wet and cold relative to modern (Fritz et al., 2007).

It is important to emphasize what the interbedded coarser and finer mud units are and what they are not. Both units are largely comprised of clastic sediments of detrital allochthonous origin. There is little sedimentary evidence that these units are turbidites - they do not have rip-up clasts or other evidence of erosive bases; they seldom form fining upward sequences. Rather we propose that these sediments are products of cold, dense, hyperpycnal flows derived from cold, sediment-rich rivers entraining shallow-water lacustrine sediments before sinking into deeper waters. The coarser units were formed during wetter periods with enhanced fluvial discharge of water and sediment and larger quantities of entrained nearshore sediment. These erosion rates were likely further enhanced by precipitation-sensitive glacial advance in the eastern Cordillera (Seltzer, 1992; Kull and Grosjean, 2000). The finer units were formed during somewhat drier periods with lower river runoff, lower wash load, and lower entrained nearshore sediment. These finer units accumulated at slightly lower rates and hence contain a higher fraction of pelagic components. The contrasting styles of deposition are somewhat similar to what we observe today between wet and dry seasons and in studies of 20th century inter-annual variability of sedimentation (Binford et al., 1992).

The spacing of the terrigenous/pelagic couplets in the stratigraphic data clearly indicates millennial variability in the Lake Titicaca record. For example, spectral analysis of the biogenic silica data (Figure 5) shows several significant (>99\%) peaks in the millennial band. These results are generally consistent, within the precision of the age model, with spectral characterizations of millennial-scale climate fluctuations from both Greenland and Antarctic ice cores (Hinnov et al., 2002) and climate records from the North Atlantic (Bond et al., 1999; Martrat et al., 2007).

Despite the limitation of our radiocarbon-derived age model, there is a reasonable correlation between the Green- 


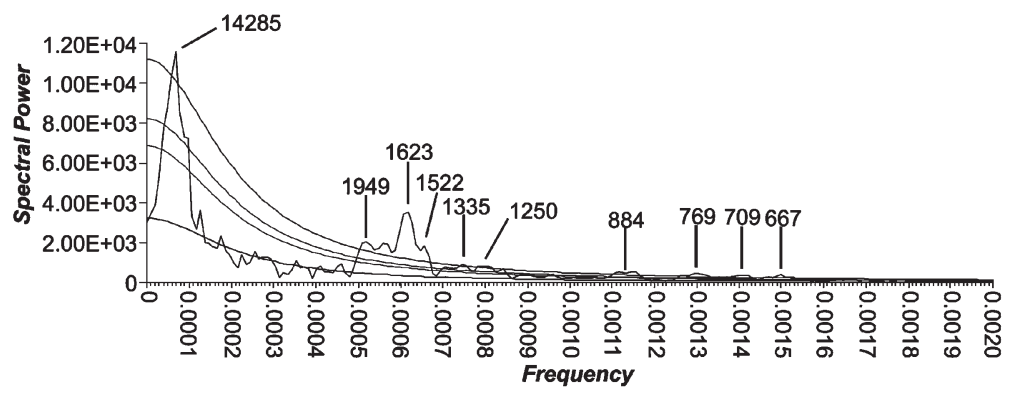

Figure 5. Multi-taper method (MTM) spectral analysis power spectrum of the BSI data from 20 to $60 \mathrm{ka}$ in the LT01-2B drill core. The confidence intervals indicated are, from top to bottom, 99, 95, 90, and 50\%. Peaks that plot above the $99 \%$ confidence interval are labeled by periodicity.

land stable isotopic record (NGRIP, 2004) and the Lake Titicaca proxy records (Figure 6). The majority (24 of 33, 75\%) of the BSi minima are clearly correlated with cold intervals (i.e. negative isotopic excursions) evident in the NGRIP record. For example, 16 numbered D-O events occur in the 60-20 ka BP interval; these events are preceded by extreme cold periods delineated by the gray bars in Figure 6. Fifteen of the 16 intervals of extreme NGRIP cold coincide within dating error with BSi minima (Figure 6). In addition, the majority (at least 9 of 17) of the other BSi minima are correlated with distinct cold periods in the NGRIP record. All of the other proxy measures (or- ganic carbon, benthic diatom fraction, grain size, and $\delta^{13} \mathrm{C}_{\text {org }}$ ) exhibit similar correlations with the NGRIP record. Moreover, this is the only portion of the Lake Titicaca drill core record where this millennial-scale alternation of coarser and finer sediments during a continuously high lake stage occurs, and its temporal coincidence with the interval of time where millennial variability is most strongly expressed in the North Atlantic region supports the hypothesis of a linkage of the Lake Titicaca record with climate variation in the high latitudes of the northern hemisphere. Thus, although a few of the coarse layers might be linked to other climatic or non-climatic forc-

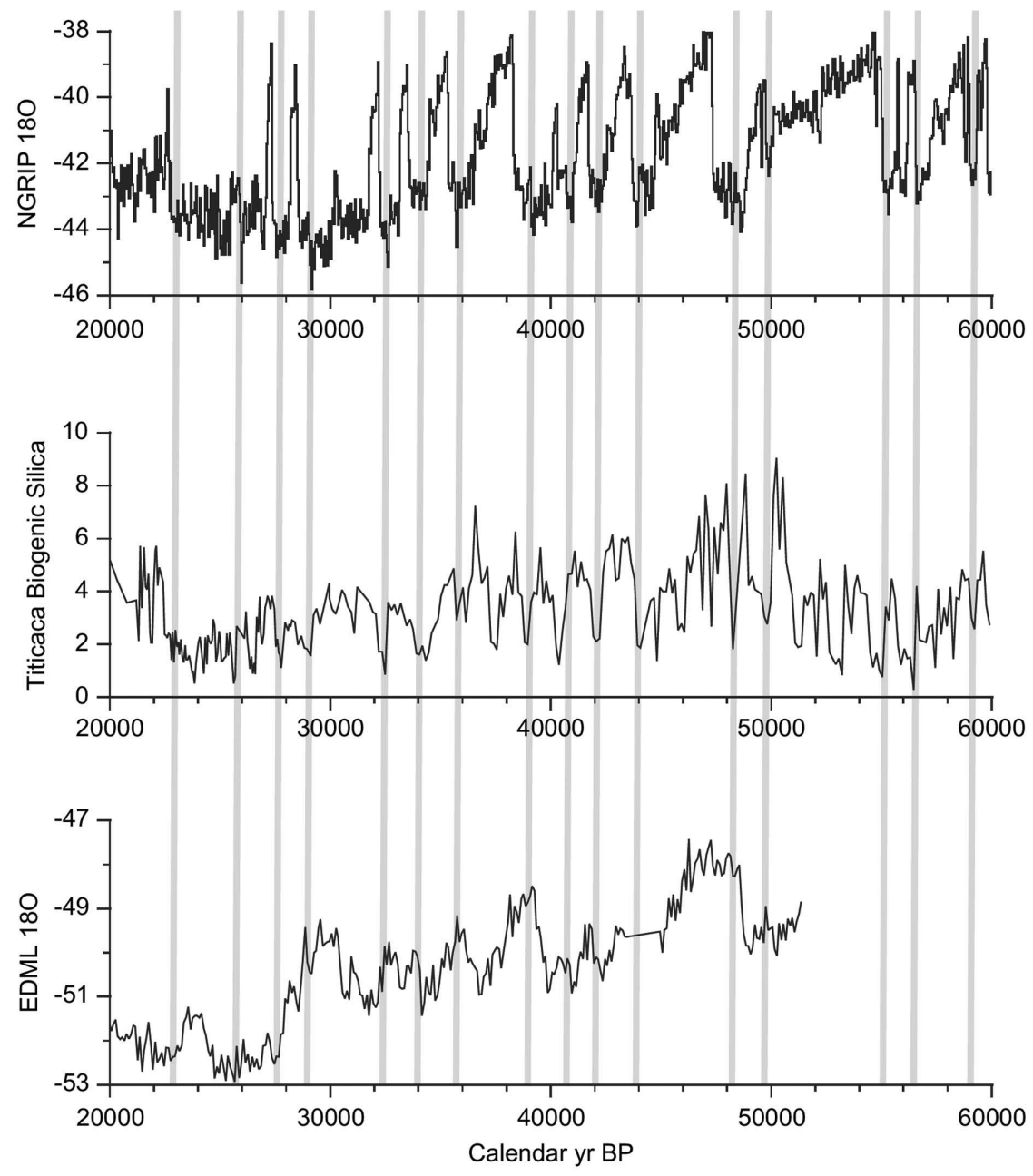

Figure 6. Comparison of the LT01-2B BSi data with high-latitude paleoclimatic time series, including NGRIP $\delta^{18} \mathrm{O}$ (NGRIP, 2004) and EDML $\delta^{18} \mathrm{O}$ (EPICA, 2006). The vertical gray lines mark the major cooling events that precede the D-O events in the NGRIP record. The majority $(\sim 75 \%)$ of BSi minima are correlated with stadial (gray vertical bars) or other major cooling events in the NGRIP record. 
ing, the parsimonious explanation for the significant millennial variation observed between 60 and $20 \mathrm{ka}$ BP in the Lake Titicaca record is a climatic connection with the North Atlantic region. The correlation between the Lake Titicaca and NGRIP records suggests that the major cold periods in the North Atlantic region were synchronous with wet periods on the Altiplano, consistent with the pattern of variation in the SASM inferred from the Botuverá Cave isotopic record.

The Lake Titicaca drill core record coupled with the Botuverá Cave isotopic record of southern subtropical Brazil (Cruz et al., 2005; Wang et al., 2004; Wang et al., 2006; Wang et al., 2007a), the Paraiso Cave isotopic record of the eastern Amazon (Wang et al., 2007b), and the speleothem and marine sedimentary records of the Brazilian Nordeste region (Arz et al., 1998; Wang et al., 2004) demonstrate that during all of Marine Isotope Stage 3, large-amplitude millennial climate variability extended throughout the entire southern tropics of South America. Moreover, this variability seems everywhere to be in phase with that of the high-latitude North Atlantic region as recorded by the NGRIP glacial isotopic record: wet conditions prevail in these South American regions during the cold stadial events of northern high latitudes.

From many previous paleoclimatic studies, it is now evident that large-amplitude perturbations of atmospheric circulation were widespread in the northern hemisphere during MIS3. In the southern tropics, at least in South America, the evidence now suggests that the northern hemisphere cold events were accompanied by increases in precipitation and continental runoff brought about by an apparent southward shift of the ITCZ in the near-equatorial Atlantic region of the continent and also were accompanied by increases of precipitation and fluvial runoff farther from the equator in the SASM region, including the tropical Andes. The observed spatial patterns of atmospheric change during the Last Glacial period seem to be completely different from the spatial patterns of rainfall variation observed today in tropical South America as a result of ENSO and PDO teleconnections (e.g. Garreaud et al., 2009). Instead of a Pacific-South American zonally-aligned teleconnection, tropical South American climate forcing during the Last Glacial seems to have been dominated by a meridionally aligned teleconnection with the North Atlantic region. Thus, perturbations to North Atlantic climate, however they came about, brought about major and rapid changes to the hydrologic balance of the South American tropics.

\section{Acknowledgments}

We thank the staff and associates of DOSECC, D. Schnurrenberger, G. Mollericon, K. Arnold, C. Veliz, J. Broda, G. Salas, J. Villanueva, J. Valdez, J. Siles, and S. Mamani for assistance with drilling and field work; as well as Autoridad Autonoma de Lago Titicaca, the Bolivian Navy, J. Sangines, DOSECC, and Crillon Tours for assistance with logistics. D. Schnurrenberger, K. Arnold, J. Smith, A. Myrbo, A. Noren, and other staff of LacCore assisted with core sampling and data management. A. Ballantyne and K. Arnold completed the carbon isotopic measurements, and P. Tapia analyzed the diatom record. Funded by U.S. National Science Foundation (ESH) and ICDP grants to PAB, SCF, and GOS.

Author contributions: PB, SF, and GS designed and managed the research; $\mathrm{SF}, \mathrm{PB}$, and $\mathrm{EE}$ contributed to analysis and interpretation of the data, and SF and PB wrote the manuscript, with contributions from EE on an earlier version. GS carried out the grain-size analyses, and LS carried out the analysis of BSi on the core.

\section{References}

Altabet et al., 2002 M. A. Altabet, M. J. Higginson, and D. W. Murray, The effect of millennial-scale changes in Arabian Sea denitrification on atmospheric $\mathrm{CO}_{2}$, Nature 415 (2002), pp. 159-162.

Arz et al., 1998 H. W. Arz, J. Patzold, and G. Wefer, Correlated millennial-scale changes in surface hydrography and terrigenous sediment yield inferred from last-Glacial marine deposits off Northeastern Brazil, Quaternary Research 50 (1998), pp. 157-166.

Baker et al., 2001 P. A. Baker, G. O. Seltzer, S. C. Fritz, R. B. Dunbar, M. J. Grove, P. M. Tapia, S. L. Cross, H. D. Rowe, and J. P. Broda, The history of South American tropical precipitation for the past 25,000 years, Science 291 (2001), pp. 640-643.

Baker et al., 2005 P. A. Baker, S. C. Fritz, J. Garland, and E. Ekdahl, Holocene hydrologic variation at Lake Titicaca, Bolivia/Peru and its relationship to North Atlantic climate variation, Journal of Quaternary Science 20 (2005), pp. 655-662.

Baker et al., $2009>$ P. A. Baker, S. C. Fritz, S. J. Burns, E. J. Ekdahl, and C. A. Rigsby, The nature and origin of decadal to millennial scale climate variability in the southern tropics of South America: the Holocene record of Lago Umayo, Peru. In: F. Vimeux, F. Sylvestre and M. Kohdri, Editors, Past Climate Variability in South America and Surrounding Regions, Developments in Paleoenvironmental Research vol. 14, Springer (2009), pp. 301-322.

Binford et al., 1992 M. W. Binford, M. Brenner, and D. R. Engstrom, Temporal sedimentation patterns in the nearshore littoral of Lago Huinaimarca. In: C. Dejoux and A. Iltis, eds., Lake Titicaca, Kluwer, Netherlands (1992), pp. 23-37.

Blunier and Brook, $2001 \longrightarrow$ T. Blunier and E. J. Brook, Timing of millennial-scale climate change in Antarctica and Greenland during the Last Glacial Period, Science 291 (2001), pp. 109-112.

Bond et al., 1999 - G. C. Bond, W. Showers, M. Elliot, M. Evans, R. Lotti, I. Hajdas, G. Bonani, and S. Johnson, The North Atlantic's 12 kyr climate rhythm: Relation to Heinrich events, Dansgaard/Oeschger cycles and the Little Ice Age. In: P. U. Clark, R. S. Webb and L. D. Keigwin, Editors, Mechanisms of Global Climate Change at Millennial Time Scales, American Geophysical Union, Washington, D. C (1999), pp. 35-58.

Bradley et al., $2003-$ R. Bradley, M. Vuille, D. Hardy, and L. G. Thompson, Low latitude ice cores record Pacific sea surface temperatures, Geophysical Research Letters 30 (2003), pp. 23-1-23-4.

Broccoli et al., 2006 A. J. Broccoli, K. A. Dahl, and R. J. Stouffer, Response of the ITCZ to Northern Hemisphere cooling, Geophysical Research Letters 33 (2006), p. L01702; doi: 10. 1029/2005GL024546.

Brown et al., 2007 E. T. Brown, T. C. Johnson, C. A. Scholz, A. S. Cohen, and J. W. King, Abrupt change in tropical African climate linked to the bipolar seesaw over the past 55,000 years, Geophysical Research Letters 34 (2007) 10. 1029/2007GL031240.

Burns et al., 2003 S. J. Burns, D. Fleitmann, A. Matter, J. Kramers, and A. A. Al-Subbary, Indian Ocean climate and an absolute chronology over Dansgaard/Oeschger Events 9 to 13, Science 301 (2003), pp. 1365-1367.

Chiang et al., 2003 J. C. H. Chiang, M. Biasutti, and D. S. Battisti, Sensitivity of the Atlantic Intertropical Convergence Zone to last Glacial maximum boundary conditions, Paleoceanography 18 (4) (2003), p. 1094; doi: 10. 1029/2003PA000916.

Chiang and Bitz, 2005 J. C. H. Chiang and C. M. Bitz, Influence of high latitude ice cover on the marine Intertropical Convergence Zone, Climate Dynamics 25 (2005), pp. 477-496.

Clement and Peterson, 2008 A. C. Clement and L. C. Peterson, Mechanisms of abrupt climate change of the last glacial period, Reviews of Geophysics 46 (2008) RG4002/2008/1-39.

Cook and Vizy, 2006 K. H. Cook and E. K. Vizy, South American climate during the Last Glacial Maximum: delayed onset of the South American monsoon, Journal of Geophysical Research 111 (2006), p. DO2110; doi: 10. 1029/2005JD005980.

Cox et al., $2008-$ P. M. Cox, P. P. Harris, C. Huntinford, R. A. Betts, M. Collins, C. D. Jones, T. E. Jupp, J. A. Marengo, and A. A. Nobre, Increasing risk of Amazonian drought due to decreasing aerosol pollution, Nature 453 (2008), pp. 212-215.

Cross et al., $2000>$ S. L. Cross, P. A. Baker, G. O. Seltzer, S. C. Fritz, and R. B. Dunbar, A new estimate of the Holocene lowstand level of Lake Titicaca, central Andes, and implications for tropical palaeohydrology, The Holocene 10 (2000), pp. 21-32.

Cruz et al., 2005 F. W. J. Cruz, S. J. Burns, I. Karmann, W. D. Sharp M. Vuille, A. O. Cardoso, J. A. Ferrari, P. L. Silva Dias, and O. J. 
Viana, Insolation-driven changes in atmospheric circulation over the past 116,000 years in subtropical Brazil, Nature 434 (2005), pp. 63-66.

Dansgaard et al., $1993 \rightarrow$ W. Dansgaard, S. J. Johnsen, H. B. Clausen, D. Dahl-Jensen, N. S. Gunderstrup, C. U. Hammer, C. S. Hvidberg, J. P. Steffensen, A. E. Sveinbjirnsdottir, J. Jouzel, and G. Bond, Evidence for general instability of past climate from a 250-kyr ice core record, Nature 364 (1993), pp. 218-220.

DeMaster, 1979 DeMaster, D. J., 1979. The Marine Budgets of Silica and ${ }^{32} \mathrm{Si}$. Ph. D. dissertation, Yale University.

EPICA, 2006 EPICA, One-to-one coupling of glacial climate variability in Greenland and Antarctica, Nature 444 (2006), pp. 195-198.

Fritz et al., $2007>$ S. C. Fritz, P. A. Baker, G. O. Seltzer, A. Ballantyne, P. M. Tapia, H. Cheng, and R. L. Edwards, Quaternary glaciation and hydrologic variation in the South American tropics as reconstructed from the Lake Titicaca drilling project, Quaternary Research 68 (2007), pp. 410-420.

Garreaud et al., 2009 R. D. Garreaud, M. Vuille, R. Compagnucci, and J. Marengo, Present-day South American climate. Palaeogeography, Palaeoclimatology, Palaeoecology 281 (2009), pp. 180-195.

Hastenrath et al., $2004 \longrightarrow$ S. Hastenrath, D. Polzin, and B. Francou, Circulation variability reflected in ice core and lake records of the southern tropical Andes, Climatic Change 64 (2004), pp. 361-375.

Hinnov et al., 2002 L. Hinnov, M. Schulz, and P. Yiouc, Interhemispheric space-time attributes of the Dansgaard-Oeschger oscillations between 100 and $0 \mathrm{ka}$, Quaternary Science Reviews 21 (2002), pp. 1213-1228.

Itambi et al., 2009 A. C. Itambi, T. von Dobeneck, S. Mulitza, T. Bickert, and D. Heslop, Millennial-scale northwest African droughts related to Heinrich events and Dansgaard-Oeschger cycles: Evidence in marine sediments from offshore Senegal, Paleoceanography 24 (2009), p. PA1205; doi: 10. 1029/2007PA001570.

Jennerjahn et al., $2004-$ T. C. Jennerjahn, V. Ittekkot, H. W. Arz, H. Behling, J. Patzold, and G. Wefer, Asynchronous terrestrial and marine signals of climate change during Heinrich events, Science 306 (2004), pp. 2236-2239.

Kittel and Richerson, $1978 \rightarrow$ T. Kittel and P. J. Richerson, The heat budget of a large tropical lake, Lake Titicaca (Peru-Bolivia), Verhandlungen, Internationalen Vereinigung fur theoretische und angewandte Limnologie 20 (1978), pp. 1203-1209.

Kull and Grosjean, $2000>$ C. Kull and M. Grosjean, Late Pleistocene climate conditions in the north Chilean Andes drawn from a climate-glacier model, Journal of Glaciology 46 (2000), pp. 622-632.

Liu et al., 2009 Z. Liu, B. L. Otto-Bliesner, F. He, E. C. Brady, R. Tomas, P. U. Clark, A. E. Carlson, J. Lynch-Stieglitz, W. Curry, E. Brook, D. Erickson, R. Jacob, J. Kutzbach, and J. Cheng, Transient simulation of Last Deglaciation with a new mechanism for Bølling-Allerød warming, Science 325 (2009), pp. 310-314.

Mann and Lees, 1996 M. E. Mann and J. M. Lees, Robust estimation of background noise and signal detection in climatic time series, Climatic Change 33 (1996), pp. 409-445.

Martrat et al., 2007 B. Martrat, J. O. Grimalt, N. J. Shackleton, L. Abreu, M. A. Hutterli, and T. F. Stocker, Four climate cycles of recurring deep and surface water destabilizations on the Iberian Margin, Science 317 (2007), pp. 502-507.

Melice and Roucou, 1998 J. Melice and P. Roucou, Decadal time scale variability recorded in the Quelccaya summit ice core ${ }^{18} \mathrm{O}$ isotopic ratio series and its relation with the sea surface temperature, Climate Dynamics 14 (1998), pp. 117-132.

NGRIP, 2004 NGRIP Members, High-resolution record of Northern Hemisphere climate extending into the Last Interglacial period, Nature 431 (2004), pp. 147-151.

Paillard et al., 1996 D. Paillard, L. Labeyrie, and P. Yiou, Macintosh program performs time-series analysis, EOS, Transactions, American Geophysical Union 77 (1996), p. 379.

Peterson et al., 2000 L. C. Peterson, G. H. Haug, K. A. Hughen, and U. Rohl, Rapid changes in the hydrologic cycle of the tropical Atlantic during the Last Glacial, Science 290 (2000), pp. 1947-1951.

Roche et al., 1992 - M. A. Roche, J. Bourges, J. Cortes, and R. Mattos, Climatology and hydrology of the Lake Titicaca basin. In: C. Dejoux and A. Iltis, eds., Lake Titicaca, Kluwer, Netherlands (1992), pp. 63-88.

Schulz et al., 1998 H. Schulz, U. von Rad, and H. Erlenkeuser, Correlation between Arabian Sea and Greenland climate oscillations of the past 100,00 years, Nature 393 (1998), pp. 54-57.
Seltzer, 1992 G. O. Seltzer, Late Quaternary glaciation of the Cordillera Real, Bolivia, Journal of Quaternary Science 7 (1992), pp. 87-98.

Seltzer et al., 2002 G. O. Seltzer, D. T. Rodbell, P. A. Baker, S. C. Fritz, P. M. Tapia, H. D. Rowe, and R. B. Dunbar, Early warming of tropical South America at the Last Glacial-Interglacial transition, Science 296 (2002), pp. 1685-1686.

Sinha et al., 2005 A. Sinha, K. G. Cannariato, L. D. Stott, L. HongChun, C. -F. You, H. Cheng, L. R. Edwards, and I. B. Singh, Variability of southwest Indian summer monsoon precipitation during the Bolling-Allerod, Geology 33 (2005), pp. 813-816.

Smith et al., 2008 J. A. Smith, B. G. Mark, and D. T. Rodbell, The timing and magnitude of mountain glaciation in the tropical Andes, Journal of Quaternary Science 23 (2008), pp. 609-634.

Stott et al., 2002 L. Stott, C. Poulsen, S. Lund, and R. Thunell, Super ENSO and global climate oscillations at millennial time scales, Science 297 (2002), pp. 222-226.

Tapia et al., $2003 \longrightarrow$ P. M. Tapia, S. C. Fritz, P. A. Baker, G. O. Seltzer, and R. B. Dunbar, A late-Quaternary diatom record of tropical climate history from Lake Titicaca (Peru and Bolivia), Palaeogeography, Palaeoclimatology, Palaeoecology 194 (2003), pp. 139-164.

Turney et al., 2004 C. S. M. Turney, A. P. Kershaw, S. C. Clemens, N. Branch, P. T. Moss, and L. K. Fifield, Millennial and orbital variations of El Nino/southern oscillation and high-latitude climate in the last glacial period, Nature 428 (2004), pp. 306-310.

Vellinga and Wood, $2002-$ M. Vellinga and R. A. Wood, Global climatic impacts of a collapse of the Atlantic thermohaline circulation, Climatic Change 54 (2002), pp. 251-267.

Voelker, 2002 A. H. L. Voelker, Global distribution of centennialscale records for marine isotope stage (MIS)3: a database, Quaternary Science Reviews 21 (2002), pp. 1185-1212.

Vuille et al., $2000 \rightarrow$ M. Vuille, R. S. Bradley, and F. Keimig, Interannual climate variability in the Central Andes and its relation to tropical Pacific and Atlantic forcing, Journal of Geophysical Research 105 (2000), pp. 12447-12460.

Vuille et al., $2003 \triangleright$ M. Vuille, R. Bradley, M. Werner, and F. Keimig, 20th century climate change in the tropical Andes: observations and model results, Climatic Change 59 (2003), pp. 75-99.

Wang et al., $2001>$ Y. J. Wang, H. Cheng, R. L. Edwards, Z. S. An, J. Y. Wu, C. Shen, and J. A. Dorale, A high resolution absolute-dated late Pleistocene monsoon record from Hulu Cave, China, Science 294 (2001), pp. 2345-2348.

Wang et al., 2004 X. L. Wang, A. S. Auler, R. L. Edwards, H. Cheng, P. S. Cristalli, P. L. Smart, D. A. Richards, and C. -C. Shen, Wet periods in northeastern Brazil over the past $210 \mathrm{kyr}$ linked to distant climate anomalies, Nature 432 (2004), pp. 740-743.

Wang et al., $2006 \checkmark$ X. Wang, A. S. Auler, R. L. Edwards, H. Cheng, E. Ito, and M. Solheid, Interhemispheric anti-phasing of rainfall during the last glacial period, Quaternary Science Review 25 (2006), pp. 3391-3403.

Wang et al., 2007a X. Wang, A. S. Auler, R. L. Edwards, H. Cheng, E. Ito, Y. Wang, X. Kong and M. Solheid, Millennial-scale precipitation changes in southern Brazil over the past 90,000 years, Geophysical Resarch Letters 34 (2007); doi: 10. 1029/2007GL031149.

Wang et al., 2007b $>$ X. Wang, A. S. Auler, R. L. Edwards, H. Cheng, E. Ito, and J. A. Dorale, Rapid Amazonian moisture oscillations correlated with Dansgaard-Oeschger cycles, Quaternary International 167-168 (2007), p. 449.

Weldeab et al., $2007 \checkmark$ S. Weldeab, D. W. Lea, R. S. Schneider, and N. Andersen, 155,000 years of West African monsoon and ocean thermal evolution, Science 316 (2007), pp. 1303-1306.

Zech et al., 2008 R. Zech, J. -H. May, C. Kull, J. Ilgner, P. W. Kubik, and $H$. Veit, Timing of the late Quaternary glaciation in the Andes from $\sim 15$ to $40^{\circ} \mathrm{S}$, Journal of Quaternary Science 23 (2008), pp. 635-647.

Zhang and Delworth, $2005 \triangleright$ R. Zhang and T. L. Delworth, Simulated tropical response to a substantial weakening of the Atlantic thermohaline circulation, Journal of Climate 18 (2005), pp. 1853-1860.

Zhou and Lau, 1998 J. Zhou and K. -M. Lau, Does a monsoon climate exist over South America?, Journal of Climate 11 (1998), pp. 1020-1040. 